\title{
Immunolocalisation of Secreted-Excreted Products of Meloidogyne spp. Using Polyclonal and Monoclonal Antibodies
}

\author{
Liziane M. Lima ${ }^{1,2,3}$, Maria F. Grossi-de-Sa ${ }^{2}$, Railene A. Pereira ${ }^{2,3} \&$ Rosane H.C. Curtis ${ }^{1}$
}

'Plant Pathogen Interactions Division, Rothamsted-Research, Harpenden, Hertfordshire AL5 2JQ, England, fax: +44

(01582) 760981, e-mail: rosane.curtis@bbsrc.ac.uk; '2Laboratório Planta-praga, Embrapa Recursos Genéticos e

Biotecnologia, Parque Estação Biológica, W5 Norte Final, Cx. Postal 02372, CEP 70770-900, Brasília, DF,

Fax: +55(61) 340-3658, e-mail: fatimasa@ cenargen.embrapa.br; ${ }^{3}$ Departamento de Biologia Celular, Universidade de Brasília, CEP 70910-900, Brasília, DF, fax: +55(61) 273-4608, e-mail: 1lima@ @enargen.embrapa.br

(Accepted for publication on 14/06/2005)

Corresponding author: Rosane H. C. Curtis

LIMA, L.M., GROSSI-DE-SA, M.F. \& CURTIS, R.H.C. Immunolocalisation of secreted-excreted products of Meloidogyne spp. using polyclonal and monoclonal antibodies. Fitopatologia Brasileira 30:629-633. 2005.

\begin{abstract}
Molecules expressed at the surface cuticle (SC) of plant parasitic nematodes represent the primary plant-nematode interface, and together with secreted-excreted (S-E) products are probably the first signals perceived by the host. These molecules, which are released into plant tissue, probably play important roles in the host-parasite interactions. Characterisation of these antigens will help in the identification of nematode targets useful for novel control strategies, which interfere with the nematode infection of plants. Three monoclonal (MAbs) and three polyclonal (PAbs) antibodies produced to S-E products of Meloidogyne spp. and Heterodera avenae were used to examine their reactivity towards $M$. incognita and/or $M$. arenaria second stage juveniles and adult females. The three PAbs showed cross-reactivity with $M$. incognita and M. arenaria. Antibody Roth-PC 373 strongly recognised molecules present in the SC, amphids and intestine, antibody Roth-PC 389 recognised the nematode amphids and metacorpus, while antibody Roth-PC 419 bound to molecules present in the subventral glands. Reactivity of the MAbs was only tested against $M$. arenaria. Monoclonal antibody Roth-MAb T116C1.1 showed intense reactivity with molecules present in the amphidial and phasmidial glands. Monoclonal antibodies Roth-MAb T46.2 and T42D.2 labeled the nematode amphids and molecules present in the nematode oesophagus (metacorpus), respectively.
\end{abstract}

Additional keywords: root-knot nematodes, surface coat, amphid, subventral and phasmidial glands, oesophagus.

\section{RESUMO}

Imunolocalização de produtos secretados-excretados de Meloidogyne spp. usando anticorpos policlonais e monoclonais

Moléculas expressadas na cutícula dos nematóides parasitas de plantas representam o primeiro contato plantanematóide e, junto com produtos secretados/excretados (S-E), são, provavelmente, os primeiros sinais percebidos pelo hospedeiro. Essas moléculas, as quais são liberadas dentro do tecido da planta, podem ter papel importante na interação parasita-hospedeiro. A caracterização desses antígenos pode ajudar na identificação de alvos para novas estratégias que interfiram na infecção de plantas por nematóides. Três anticorpos monoclonais e três anticorpos policlonais produzidos para secreções-excreções de Meloidogyne spp. e Heterodera avenae foram usados para examinar a reatividade a juvenis de segundo estádio (J2) e/ou fêmeas de $M$. incognita e $M$. arenaria. Os três anticorpos policlonais mostraram reação tanto para $M$. incognita quanto para $M$. arenaria. Roth-PC 373 reconheceu fortemente moléculas presentes na cutícula, anfídios e intestino, Roth-PC 389 reconheceu anfidios e metacorpo, enquanto Roth-PC 419 ligou-se a moléculas presentes nas glândulas subventrais. A reatividade dos MAbs foi testada somente com M. Arenaria. Roth-MAb T116C1.1 reagiu intensamente com moléculas presentes nas glândulas anfidial e fasmidial. Roth-MAb T46.2 e T42D.2 marcaram anfídios e moléculas presentes no esôfago (metacorpo) do nematóide, respectivamente.

Palavras-chave adicionais: nematóide das galhas, cutícula, glândulas subventrais, glândula fasmidial, glândula amphidial, esôfago.

\section{INTRODUCTION}

Root-knot nematodes (Meloidogyne spp.) are highly polyphagous plant sedentary endoparasites, which cause major crop losses in agriculture worldwide (Sasser, 1980; Sasser and Freckman, 1987). Plant-parasitic nematodes have diverse parasitic relationships with their host plants in order to obtain the nutrients necessary for their development and reproduction. Nematode species that are evolutionarily advanced become sedentary and feed from a single cell or a group of cells for prolonged periods of time (Hussey et al., 2002). Meloidogyne spp establish a permanent feeding site in the differentiation zone of the root by inducing nuclear division without cytokinesis in host cells (Williamson \& 
Gleason, 2003), modulating complex changes in plant cell gene expression, physiology, morphology and function (Gheysen and Fenoll, 2002). These nematodes spend most of their life cycle inside the roots, where they undergo distinct changes in morphology; they pass through three consecutive moults in developing from a second stage juvenile (J2) to a globose sedentary adult female (Bird \& Bird, 1998). The change in morphology is accompanied by biochemical and ultra-structural changes in the surface cuticle (SC). The cuticle is a complex structure that is involved in the motility, maintenance of morphology and interactions with the external environment (Blaxter \& Robertson, 1998). Molecules expressed at the SC of these parasitic nematodes represent the primary host-parasite interface, and together with secreted-excreted products are probably the first signals perceived by the host (Lopez de Mendonça et al., 1999). Nematode surfaces have a coat which contains different carbohydrates probably in the form of glycoproteins (Gems \& Maizels, 1996). Among the nematode's secretory products, stylet secretions are believed to play a role in the penetration and migration through root tissue, modification and maintenance of root cells as feeding sites, formation of feeding tubes, and digestion of host cell contents to facilitate nutrient acquisition by the nematode (Hussey, 1989). These secretions are produced by two subventral and one dorsal oesophageal gland cells and are secreted through the stylet into the plant tissue during parasitism (Davis et al., 2004). Over the last decade, research has focused on the secretions of plant parasitic nematodes, in particular those of the cuticle, amphids and oesophageal glands, which are considered to be involved in several aspects of the infection process (Fioretti et al., 2001). In this present study, different polyclonal and monoclonal antibodies raised against some secreted-excreted (SE) products of Meloidogyne spp. and Heterodera avenae (Curtis, 1996; Curtis et al., 1997; Sharon et al., 2002) were used to characterise in vitro binding to the SC, amphids, subventral glands, phasmidial glands, metacorpus and intestine of $\mathrm{J} 2$ and adults females of $M$. incognita and the $\mathrm{J} 2$ of $M$. arenaria.

\section{MATERIALS AND METHODS}

\section{Nematodes}

Second stage juveniles (J2) and females of $M$. incognita race 1 from North Carolina State University and $\mathrm{J} 2$ of $M$. arenaria from the University of Coimbra were obtained from infected tomato (Lycopersicon esculentum Mill.) plants cv. Tiny Tim. Egg masses were colleted as described by Hussey \& Barker (1973) and adult females were dissected from infected tomato roots.

\section{Antibodies}

Polyclonal antibodies (PAbs) were previously raised in rabbits: Roth-PC 373 (live pre-parasitic J2 and SC extract of $M$. incognita), Roth-PC 389 (SE products from $M$. incognita) (Sharon et al., 2002) and Roth-PC 419 (SE products from $M$. arenaria) produced as described in Curtis (1996). The monoclonal antibodies (MAbs) were previously raised in mice (Curtis, 1996) to plant parasitic nematodes: Roth-MAb T116C1.1 and Roth-MAb T42D.2 were prepared using homogenate of pre-parasitic $\mathrm{J} 2$ and SC extract of live pre-parasitic J2 of $M$. incognita; Roth-MAb T46.2 was prepared using $H$. avenae cyst homogenate as described in Curtis et al. (1997).

\section{Indirect immunofluorescence for nematode pieces and cryosections}

Freshly hatched $M$. incognita and $M$. arenaria $\mathrm{J} 2$ were pelleted by centrifugation and used to prepare nematode pieces and cryosections $(30 \mu \mathrm{m})$, respectively. These were prepared and processed as described by De Boer et al. (1996) and Curtis (1996). The immunolabelling procedure utilizing monoclonal and polyclonal antibodies described above was done according to Fioretti et al. ( 2001) and Sharon et al. (2002).

\section{Enzyme Linked Immunosorbent Assay}

Microtitre-enzime linked immunosorbent assay (Elisa) plates (Nunc-immunoplate) were coated overnight at $4{ }^{\circ} \mathrm{C}$ with $50 \mu \mathrm{l}(10 \mu \mathrm{g} / \mathrm{ml})$ of nematode antigens and the ELISA test was performed as described by Curtis et al. (1996).

\section{SDS-PAGE and Western blotting}

One dimensional SDS-PAGE was carried out following the methodology described by Laemmli (1970). Antigen samples of $M$. incognita and $M$. arenaria J2 were prepared as described in Fioretti et al. (2001). Western blotting of proteins was performed using standard protocol (Sambrook et al., 1989) utilising the antibodies Roth-PC 373, Roth-PC 389, Roth-MAb T116C1.1 and Roth-MAb T42D.2.

\section{RESULTS}

\section{Immunofluorescence studies}

In the immunolocalisation assays, all the antibodies used in this study bound to the amphids. Two out of three PAbs reacted with the SC and other structures. The three PAbs (Roth-PC 373, Roth-PC 389 and Roth-PC 419) tested showed cross-reactivity with pre-parasitic $\mathrm{J} 2$ of $M$. incognita and $M$. arenaria. Immunofluorescence with $\mathrm{J} 2$ of $M$. incognita showed that Roth-PC 373 reacted with SC and amphids (Figure 1a), Roth-PC 419 reacted with the subventral glands (Figure 1b) and amphids, and Roth-PC 389 reacted with amphids (data not shown). Moreover, RothPC 373 labelled with the SC, amphidial pores (Figure 1c) and intestine in $\mathrm{J} 2$ of $M$. arenaria (Figure 1d). Antibody Roth-PC 389 labelled amphids and the metacorpus, and Roth-PC 419 labelled amphids, SC and intestine (data not shown). Strong reactivity, especially in the amphids was also detected when MAbs were probed in 
immunofluorescence tests with $\mathrm{J} 2$ of $M$. arenaria. Also, Roth-MAb T46.2 reacted with the metacorpus, Roth-MAb T116C1.1 reacted with the phasmidial glands and RothMAb T42D.2 labelled the oesophagus (data not shown). None of the MAbs tested showed reactivity with the SC of $M$. arenaria. No immunofluorescence was observed with the negative control, which consisted of the medium (20D) used to grow the cell lines secreting antibodies.

\section{Elisa assay}

All monoclonal and polyclonal antibodies tested reacted with antigens present in the homogenates of $\mathrm{J} 2$ of $M$. incognita and $M$. arenaria using indirect Elisa assay. Antigens were also present in the homogenate of females, but in lower concentration, except for the antibody RothPC 373. This antibody strongly recognised antigens in $M$. incognita females (Figure 2a). The antibodies Roth-PC 389 and Roth-MAb T46.2 weakly recognised antigens present in all the nematode samples tested (Figure 2a, b). Boiling nematode homogenates for $10 \mathrm{~min}$, prior to the Elisa did not affect their reactivity with the antibodies.

\section{Analysis by Western Blots}

Antibodies Roth-PC 373, Roth-PC 389, Roth-MAb T116C1.1 and Roth-MAb T42D.2 were tested by Western blot using $M$. incognita and $M$. arenaria $\mathrm{J} 2$ homogenates. Roth-PC 373 labelled a broader range of proteins in the homogenate of $M$. incognita. Common bands were also present in homogenate of $M$. arenaria, with apparent molecular weights of $20 \mathrm{kDa}$ and $37 \mathrm{kDa}$ (Figure 3, line 1 and 2). Roth-PC 389 recognised a series of bands between $<14 \mathrm{kDa}$ and >94 $\mathrm{kDa}$ in $M$. incognita, and two common bands were observed in $M$. arenaria, with molecular weights of approximately $33 \mathrm{kDa}$ and $64 \mathrm{kDa}$ (data not shown). The MAbs Roth-MAb T116C1.1 and Roth-MAb T42D.2 labelled a single protein band of approximately $94 \mathrm{kDa}$ in $M$. incognita (Figure 3, line 3 and 4). In contrast, no reactivity was observed with $M$. arenaria.

\section{DISCUSSION}

All polyclonal and monoclonal antibodies analysed reacted with antigens present in the amphids of both nematode species $M$. incognita and $M$. arenaria, indicating these amphidial antigens cross react in both species of Meloidogyne tested. The monoclonal antibody, Roth-MAb T116C1.1, recognised antigens present in amphidial and phasmidial glands of $M$. arenaria. The amphids and phasmids are sensory organs, which appear to be chemosensory because they are associated with openings in the nematode cuticle which allow enclosed neurons to contact the external environment (Freitas et al., 2001). The nematodes tested possess two bilaterally symmetrical amphids and phasmids, located in the nematode head and tail, respectively. They may be involved in host recognition and have been implicated in aiding the nematode to locate

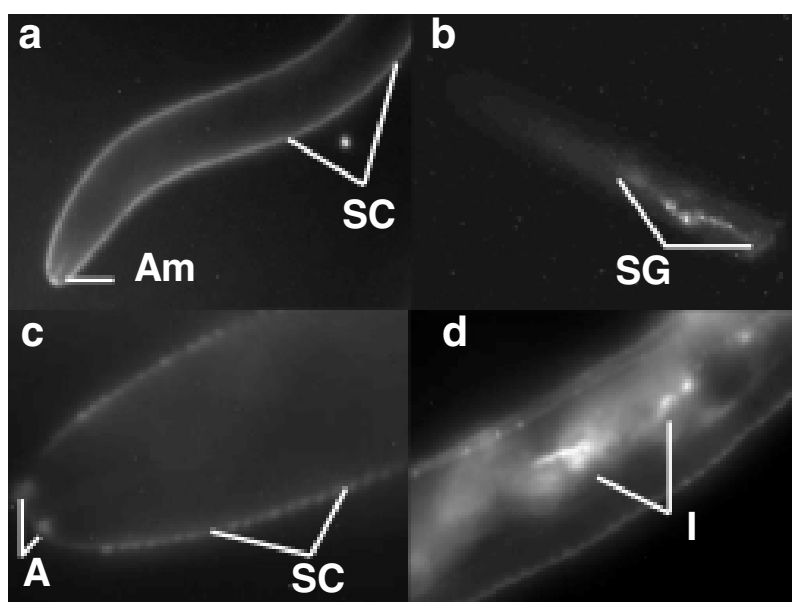

FIG. 1 - Immunoflurescence labelling of $\mathrm{J} 2$ of Meloidogyne incognita $(M i)$ and $M$. arenaria $(M a)$. Reactivity of polyclonal antibodies against $\mathrm{J} 2$ of $M$. incognita $(M i)$ and $M$. arenaria $(M a)$. a - Roth-PC 373 labelling the $M i$ surface coat (SC) and amphid (Am); b - Roth-PC 419 labelling the $M i$ subventral gland (SG); c - Roth-PC 373 labelling the Ma SC and amphidial pore (AP); d Roth-PC 373 labelling the Ma intestine (I).

its host. Studies reported by Sharon et al. (2002) also showed cross-reactivity with $M$. javanica of several antibodies, which had been raised against $M$. incognita.

Two of the three PAbs, Roth-PC 373 and Roth-PC 419 , bound to the amphids and also bound to SC and the intestine of $M$. incognita and $M$. arenaria, respectively. Cross-reactive immunodominant epitopes present in the amphids and cuticle of plant parasitic nematodes may be involved in physiological mechanisms shared by these nematodes. Moreover, the nematode cuticle selectively regulates the flow of fluids through the body wall and could be a source of secreted compounds recognized as signal molecules by plants (Abad et al., 2003). This inhibitory effect of antibodies on nematode movement and infection of plants has been demonstrated by Sharon et al. (2002) and Fioretti et al. (2003), implicating amphidial and cuticular antigens as good targets for devising novel nematode control strategies.

The antibody Roth-PC 419 also recognised $M$. incognita subventral glands and $M$. arenaria intestine. Oesophageal gland secretions are considered to contain products of the parasitism genes (Hussey et al., 2002). These secreted products can be involved in the degradation of plant cell walls, as cellulases (Rosso et al., 1999), pectate lyase (De Boer et al., 2002; Popeijus et al., 2000) and chorismate mutase (Lambert et al., 1999). Most efforts in analysing nematode secretions have focused on proteins secreted from amphids and eosophageal glands.

The antibodies were used in indirect Elisa to investigate the stage specificity of the molecules they recognize. Antibodies Roth-PC 389, PC 419, MAb T46.2, 

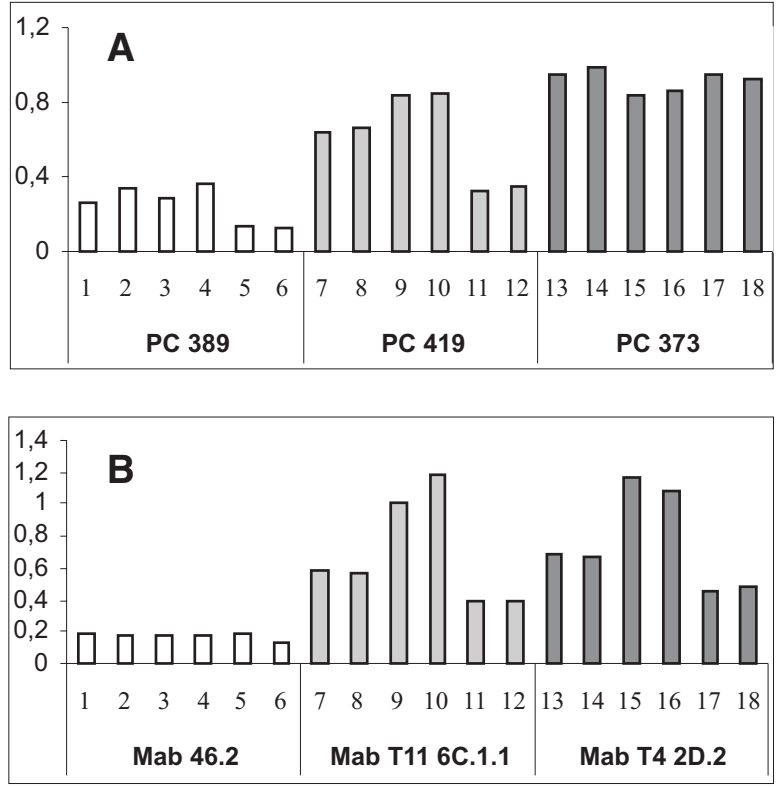

FIG. 2 - Indirect Elisa of homogenates, untreated and heat treated, of Meloidogyne arenaria $(\mathrm{Ma})$ and $\mathrm{M}$. incognita (Mi) J2. APolyclonal antibodies; B- Monoclonal antibodies. 1- $M a / J 2 \mathrm{nt} ; 2$ $M a / J 2$ t; 3- $M i / J 2$ nt; 4- $M i / J 2$ t; 5- $M i / F$ nt; 6- $M i / F$ t; 7- $M a / J 2$ nt; 8- $M a / J 2$ t; 9- $M i / J 2$ nt; 10- $M i / J 2$ t; 11- $M i / F$ nt; 12- $M i / F$ t; 13$M a / \mathrm{J} 2$ nt; 14- $M a / \mathrm{J} 2$ t; 15- $M i / J 2$ nt; 16- $M i / J 2$ t; 17- $M i / F$ nt; 18$\mathrm{Mi} / \mathrm{F}$ t. J2: second stage Juvenile; F: Females; nt: untreated; t: treated.

MAb T116C1.1 and MAb T42D.2 reacted strongly with the $\mathrm{J} 2$ and poorly with the adult females, indicating that these antibodies are recognising epitopes which are produced in the early stages of the nematode life cycle. In contrast, RothPC 373 showed strong reactivity towards antigens present in the $\mathrm{J} 2$ and females, indicating that these molecules might play a role in both stages of nematode development. Furthermore, the antibodies tested may be recognizing carbohydrate epitopes; the nematode amphid and cuticle surface secretions are formed by different carbohydrates, probably glycoproteins (Gems \& Maizels, 1996). Sugar residues were identified on both the surface coat and amphids of some species of nematodes (Robertson et al., 1989).

Western blot analysis, using the antibody Roth-PC 373, revealed antigen bands in M. incognita and M. arenaria $\mathrm{J} 2$, with the same molecular weights, which indicate that identical protein epitopes are present in the two different species of nematodes studied and might also be present in different stages of the life-cycle of theses nematodes. The Roth-PC 389 labelled a series of bands between $<14$ and $>94 \mathrm{kDa}$ in $M$. incognita homogenate and two common bands in $M$. arenaria homogenate. The MAbs Roth-MAb T116C1.1 and Roth-MAb T42D.2 recognised one single band in homogenates of $\mathrm{J} 2$ of $M$. incognita with similar molecular weights. These antigens may represent dominant

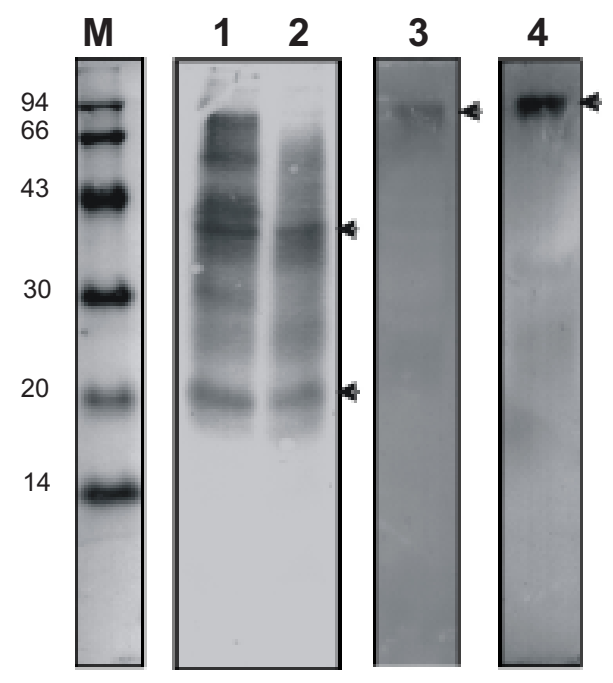

FIG. 3 - Western blot of homogenates of Meloidogyne incognita (Mi) and M. arenaria (Ma) J2. M- Marker; 1 - Mi + Roth-PC 373; 2- $M a+$ Roth-PC 373; 3- Mi + Roth-T116C1.1; 4- Mi + RothT42D.2.

epitopes presents in the amphids, metacorpus or intestine. Many antigens involved in parasitism of plant-parasitic and animal-parasitic nematodes have been found in the range of 14-94 kDa (Lopez de Mendonça et al., 1999).

The identification of molecules secreted by plant nematodes in planta might represent potential targets for the development of novel alternatives to control economically important plant parasitic nematodes. The expression in plants of antibodies affecting the infection of nematodes in the roots is a promising alternative to reduce crops losses.

\section{ACKNOWLEDGEMENTS}

Rothamsted-Research receives grant-aided support from the Biotechnology and Biological Sciences Research Council of the United Kingdom. Cultures of nematodes were maintained under the criteria defined under DEFRA licence PHL174C/4813(04/2004).

\section{LITERATURE CITED}

ABAD, P., FAVERY, B., ROSSO, M.N. \& CASTAGNONESERENO, P. Root-knot nematode parasitism and host response: molecular basis of a sophisticated interaction. Molecular Plant Pathology 4:217-224. 2003

BIRD, A.F. \& BIRD, J. Introduction to functional organization. In: Perry, R.N. \& Wright, D.J. (Eds.) The physiology and biochemistry of free-living and plant-parasitic nematodes. UK. CAB International. 1998. pp.1-24.

BLAXTER, M.L. \& ROBERTSON, W. The cuticle. In: Perry, R.N. \& Wright, D.J. (Eds.) The physiology and biochemistry of free- 
living and plant-parasitic nematodes. Wallingford, UK. CAB International. 1998. pp.25-48

CURTIS, R.H.C. Identification and in situ and in vitro characterization of secreted proteins produced by plant-parasite nematodes. Parasitology 113:589-597. 1996.

CURTIS, R.H.C., AL-HINAI, M.S., DIGGINES, A.E.R. \& EVANS, K. Serological identification and quantification of Heterodera avenae from processed soil samples. Nematologica 43:199-213. 1997.

CURTIS, R.H.C., BENDEZU, I.F. \& EVANS, K. Identification and localization of a putative actin in the two species of potato cyst nematodes using a monoclonal antibody. Fundamental Applied Nematology 19:421-426. 1996.

DAVIS, E.L., HUSSEY, R.S. \& BAUM, T.J. Getting to the roots of parasitism by nematodes. Trends in Parasitology 20:134-141. 2004.

DE BOER, J.M., OVERMARKS, H.A., POMP, H.R., DAVIS, E.L., ZILVERENTANT, J.F., GOVERSE, A., SMANT, G., STOKKERMMANS, J.P.W.G., HUSSEY, R.S., GOMMERS, F.J., BARKER, J. \& SCHOTS, A. Production and characterization of monoclonal antibodies to antigens from second stage juveniles of potato cyst nematode Globodera pallida. Parasitology 115:429438. 1996.

DE BOER, J.M., MCDERMOTT, J.P., DAVIS, E.L., HUSSEY, R.S., SMANT, G. \& BAUM, T.J. Cloning of a putative pectate lyase gene expressed in the subventral esophageal glands of Heterodera glycines. Journal of Nematology 33:9-11. 2002.

FIORETTI, L., WARRY, A., PORTER, A., HAYDOCK, P. \& CURTIS, R. Isolation and localization of an annexin gene ( $\mathrm{gp}$ nex) from potato cyst nematode, Globodera pallida. Journal of Nematology 3:45-54. 2001.

FIORETTI, L. PORTER, A., HAYDOCK, P. \& CURTIS, R.H.C. Monoclonal antibodies reactive with secreted-excreted products from the amphids and the cuticle surface of Globodera pallida affect nematode movement and delay invasion of potato plants. International Journal for Parasitology 32:1709-171. 2003

FREITAS, L.G., OLIVEIRA, R.D.L. \& FERRAZ, S. Introdução à Nematologia. $1^{\text {st }}$ ed. Minas Gerais. UFV. 2001.

GEMS, D. \& MAIZELS, R.M. An abundantly expressed mucinlike protein from Toxocara canis infective larvae: The precursor of the larval surface coat glycoproteins. Medical Sciences 93:16651670. 1996.

GHEYSEN, G. \& FENOLL, C. Gene expression in nematode feeding sites. Annual Review of Phytopatology 40:124-168. 2002. HUSSEY, R.S. Disease-induced secretions of plant parasitic nematodes. Annual Review of Phytopathology 27:123-141. 1989.
HUSSEY, R.S. \& BARKER, A. A comparison of methods of collecting inocula for Meloidogyne spp. including a new technique. Plant Disease Reporter 57:1025-1028. 1973.

HUSSEY, R.S., DAVIS, E.L. \& BAUM, T.J. Secrets in secretions: genes that control nematode parasitism of plants. Brazilian Journal of Plant Physiology 14:183-194. 2002.

LAEMMLI , U.K. Cleavage of structural proteins during the assembly of the head of bacteriophage T4. Nature 227:680-685. 1970.

LAMBERT, K.N., ALLEN, K.D. \& SUSSEX, I.M. Cloning and characterization of an esophageal-gland-specific chorismate mutase from the phytoparasitic nematode Meloidogyne javanica. Molecular Plant-Microbe Interactions 12:328-336. 1999.

LOPEZ DE MENDONÇA, M.E., CURTIS, R.H.C. \& GOWEN, $\mathrm{S}$. Identification and characterization of excreted-secreted products and surface coat antigens of animal and plant-parasitic nematodes. Parasitology 118:397-405. 1999.

POPEIJUS, H., OVERMARS, H., JONES, J., BLOCK, V., GOVERSE, A., HELDER, J., SCHOTS, A., BAKKER, J. \& SMANT, G. Enzymology - Degradation of plant cell walls by a nematode. Nature 406: 36-37. 2000.

ROBERTSON, W.M., SPIEGEL, Y., JANSSON, H.B., MARBANMENDONÇA, N. \& ZUCKERMAN, B.M. Surface carbohydrates of plant parasitic nematodes. Nematologica, 35:180-186. 1989.

ROSSO, M.N., FAVERY, B., PIOTTE, C., ARTHAUD, L., DE BOER, J.M., HUSSEY, R.S., BAKKER, J., BAUM, T.J. \& ABAD, P. Isolation of a cDNA encoding a â-1,4-endoglucanase in the rootknot nematode Meloidogyne incognita and expression analysis during plant parasitism. Molecular Plant-Microbe Interactions 12:585-591. 1999.

SAMBROOK, J., FRITSCH, E.F. \& MANIATIS, T. Molecular cloning a laboratory manual. Cold Spring Harbor. New York. Cold Spring Harbor Laboratory Press. 1989. p.545.

SHARON, E., SPIEGEL, Y., SALOMON, R. \& CURTIS, R.H.C. Characterization of Meloidogyne javanica surface coat with antibodies and their affect on nematode behaviour. Parasitology 125:177-185. 2002.

SASSER, J.N. Root-knot nematodes: A global menace to crop production. Plant Disease 64:36-41. 1980.

SASSER, J.N. and D.W. FRECKMAN. A World Perspective on Nematology: The Role of the Society. In: Veech, J.A. \& Dickson, D.W. (Eds.) "Vistas on Nematology." Society of Nematologists Inc., Hyattsville, MD. 1987.

WILLIAMSON, V.M. \& GLEASON, C.A. Plant-nematode interactions. Current Opinion in Plant Biology 6:327-333. 2003. 